Supplementary data and experimental details for:

\title{
Ribosomal elongation of aminobenzoic acid derivatives
}

\author{
Takayuki Katoh*, Hiroaki Suga* \\ Department of Chemistry, Graduate School of Science, The University of Tokyo, 7-3-1 Hongo, \\ Bunkyo-ku, Tokyo 113-0033, Japan \\ *To whom correspondence should be addressed. Tel: +81-3-5841-8372; Fax: +81-3-5841-8372; \\ E-mail: katoh@chem.s.u-tokyo.ac.jp (T.K.), hsuga@chem.s.u-tokyo.ac.jp (H.S.)
}




\section{Table of Contents}

\begin{tabular}{|l|l|}
\hline $\begin{array}{l}\text { Supplementary Figure S1. Secondary structures of a microhelix RNA and tRNAs used for } \\
\text { aminoacylation. }\end{array}$ & $\mathrm{S} 3$ \\
\hline Supplementary Figure S2. Substrates used in aminoacylation reaction. & $\mathrm{S} 3$ \\
\hline $\begin{array}{l}\text { Supplementary Figure S3. Aminoacylation of } \mu \mathrm{hRNA} \text { using amino acid NCAs analyzed by } \\
\text { acid denaturing PAGE. }\end{array}$ & $\mathrm{S} 6$ \\
\hline $\begin{array}{l}\text { Supplementary Figure S4. MALDI-TOF mass spectra of aminoacyl- } \mu \text { hRNAs prepared by } \\
\text { means of amino acid NCAs. }\end{array}$ & $\mathrm{S} 7$ \\
\hline $\begin{array}{l}\text { Supplementary Figure S5. Aminoacylation of } \mu \mathrm{hRNA} \text { using CME-activated amino acids } \\
\text { and eFx analyzed by acid denaturing PAGE. }\end{array}$ & $\mathrm{S} 8$ \\
\hline $\begin{array}{l}\text { Supplementary Figure S6. MALDI-TOF mass spectra of aminoacyl- } \mu \text { hRNAs prepared by } \\
\text { eFx. }\end{array}$ & $\mathrm{S} 10$ \\
\hline $\begin{array}{l}\text { Supplementary Figure S7. Tricine SDS-PAGE analysis of model peptides rP1 containing } \\
\text { Abz derivatives. }\end{array}$ & $\mathrm{S} 11$ \\
\hline $\begin{array}{l}\text { Supplementary Figure S8. Tricine SDS-PAGE analysis of model peptides rP1-rP4 } \\
\text { containing Abz. }\end{array}$ & $\mathrm{S} 11$ \\
\hline Materials and methods & $\mathrm{S} 12$ \\
\hline References for supplementary information & $\mathrm{S} 13$ \\
\hline
\end{tabular}




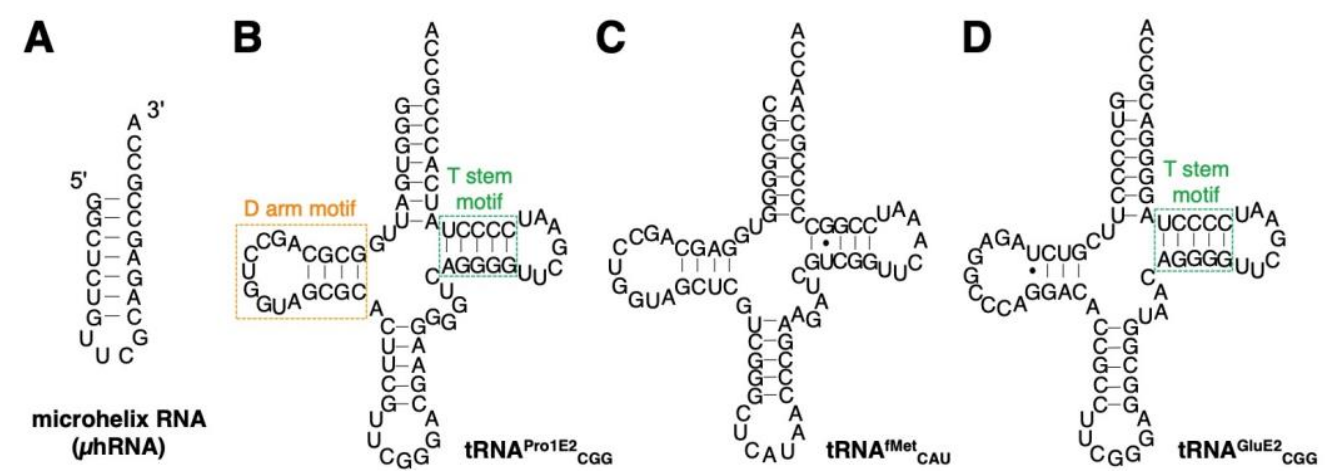

Supplementary Figure S1. Secondary structures of a microhelix RNA and tRNAs used for aminoacylation. (A) Secondary structure of microhelix RNA. (B) tRNA ${ }^{\text {ProlE2 }}$ CGg used for decoding CCG codons. The D-arm motif for EF-P binding consists of a 9-nt D-loop closed by a stable 4-bp stem and is indicated in orange. The T-stem motif for improved EF-Tu binding is indicated by green. The sequence of anticodon loop is changed accordingly for decoding other codons. See supplementary Table S2 for the sequences. (C) tRNA ${ }^{\mathrm{fMet}} \mathrm{CAU}$ used for incorporation of ${ }^{\mathrm{ClAc}} \mathrm{D}-\mathrm{Tyr}$ and ${ }^{\mathrm{ClAc}} \mathrm{D}-\mathrm{Ph}$ at the initiator AUG codon. (D) tRNA ${ }^{\mathrm{GluE2}}{ }_{\mathrm{CGG}}$ used for incorporation of $(1 S, 2 S)-2-\mathrm{ACPC}$ at CCG codon.

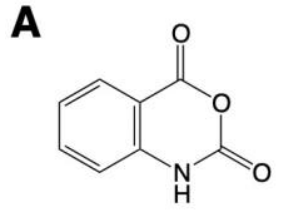

Isatoic anhydride<smiles>O=c1[nH]c2ccc(O)cc2c(=O)o1</smiles>

5-Hydroxyisatoic anhydride

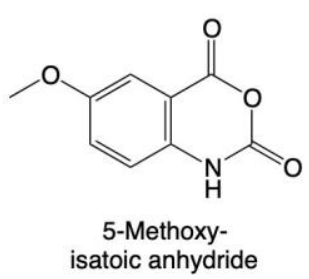

isatoic anhydride

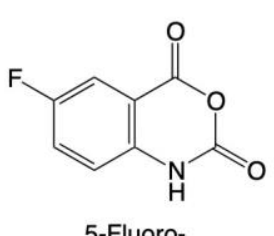

5-Fluoroisatoic anhydride

B<smiles>N#CCOC(=O)c1ccncc1N</smiles><smiles>N#CCOC(=O)c1sccc1N</smiles>

3-Aminothiophene2-carboxylic acid cyanomethyl ester (Atp-CME)<smiles>N#CCOC(=O)c1ncsc1N</smiles>

5-Aminothiazolecyanomethyl ester (Atz-CME)<smiles>N#CCOC(=O)c1cccc(N)c1</smiles>

$$
\begin{aligned}
& \text { 3-Aminobenzoic acid } \\
& \text { cyanomethyl ester } \\
& \text { ('NAbz-CME) }
\end{aligned}
$$

Supplementary Figure S2. Substrates used in aminoacylation reaction. (A) Substrates used in NCA aminoacylation. Isatoic anhydride, 5-hydroxyisatoic anhydride, 5-methoxyisatoic anhydride, and 5-fluoroisatoic anhydride were used for charging $\mathrm{Abz}, \mathrm{Abz}^{5 \mathrm{OH}}, \mathrm{Abz}^{5 \mathrm{OMe}}$, and $\mathrm{Abz}^{5 \mathrm{~F}}$, respectively. (B) Substrates used in eFx-catalyzed aminoacylation. Cyanomethyl esters of Apy, Atp, Atz, and ${ }^{3 \mathrm{~N}} \mathrm{Abz}$. (C,D,E,F) NMR spectra of cyanomethyl esters of Apy (C), Atp (D), Atz (E), and ${ }^{3 \mathrm{~N}} \mathrm{Abz}(\mathrm{F})$. 


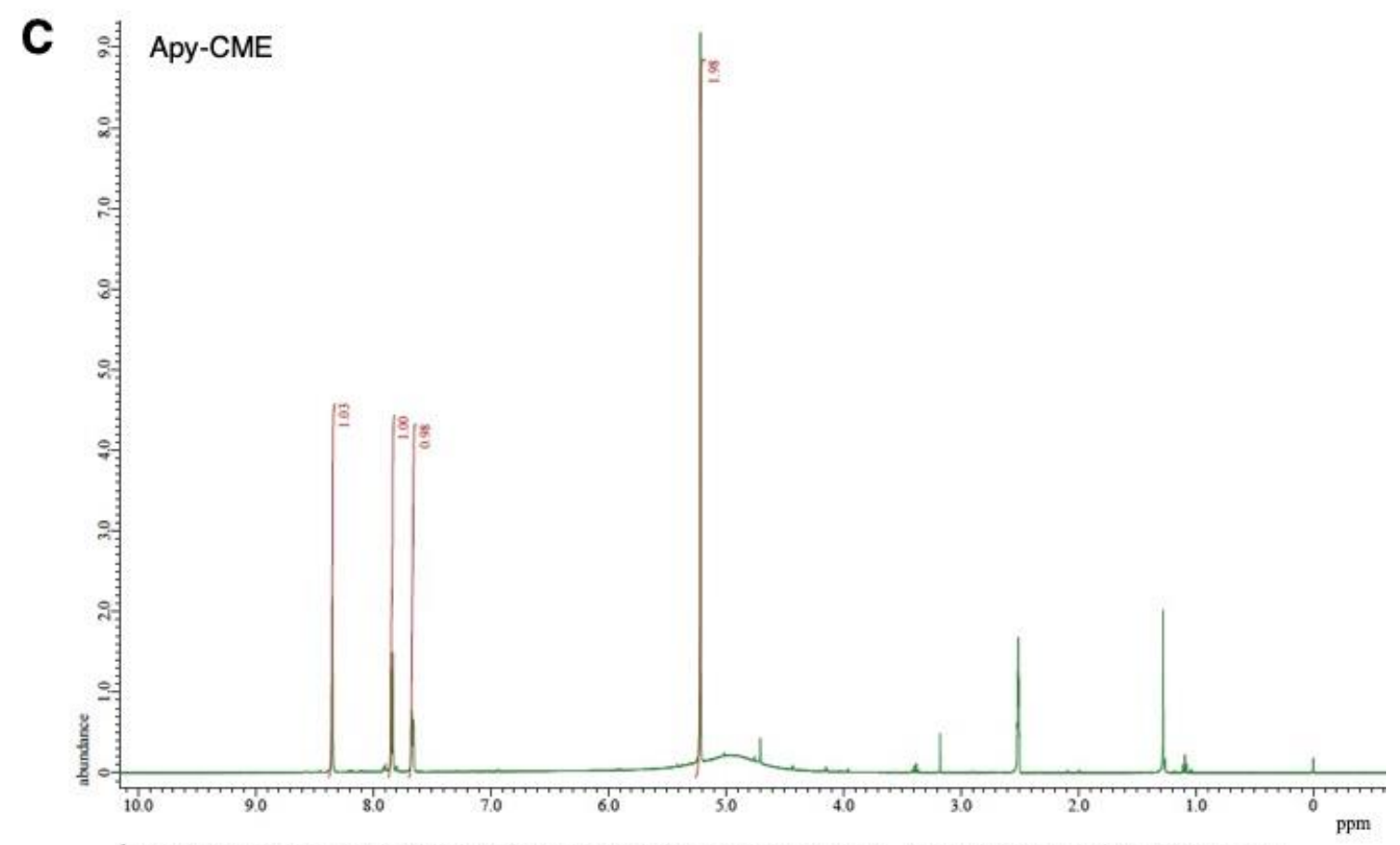

${ }^{1} \mathrm{H}$ NMR $\left(400 \mathrm{MHz}, \mathrm{DMSO}_{6} \mathrm{~d}_{6}\right): 88.346(\mathrm{~s}, 1 \mathrm{H}), 7.847-7.833(\mathrm{~d}, J=5.6 \mathrm{~Hz}, 1 \mathrm{H}), 7.674-7.658(\mathrm{~d}, J=6.4 \mathrm{~Hz}, 1 \mathrm{H})$, $5.214(\mathrm{~s}, 2 \mathrm{H})$

\section{D}

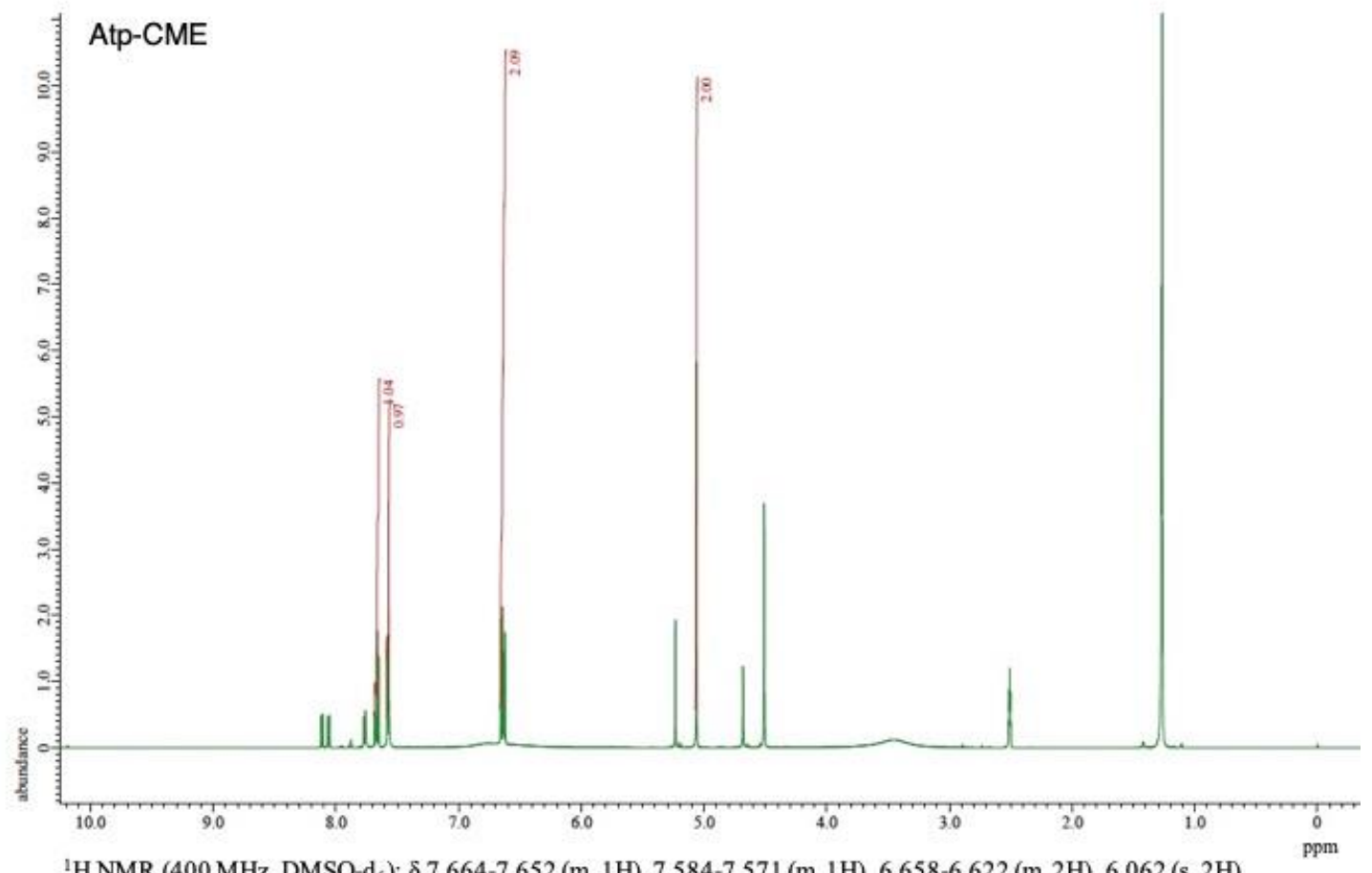

${ }^{1} \mathrm{H}$ NMR $\left(400 \mathrm{MHz}\right.$, DMSO-d $\left.\mathrm{d}_{6}\right): 87.664-7.652(\mathrm{~m}, 1 \mathrm{H}), 7.584-7.571(\mathrm{~m}, 1 \mathrm{H}), 6.658-6.622(\mathrm{~m}, 2 \mathrm{H}), 6.062(\mathrm{~s}, 2 \mathrm{H})$

Supplementary Figure S2, continued. 


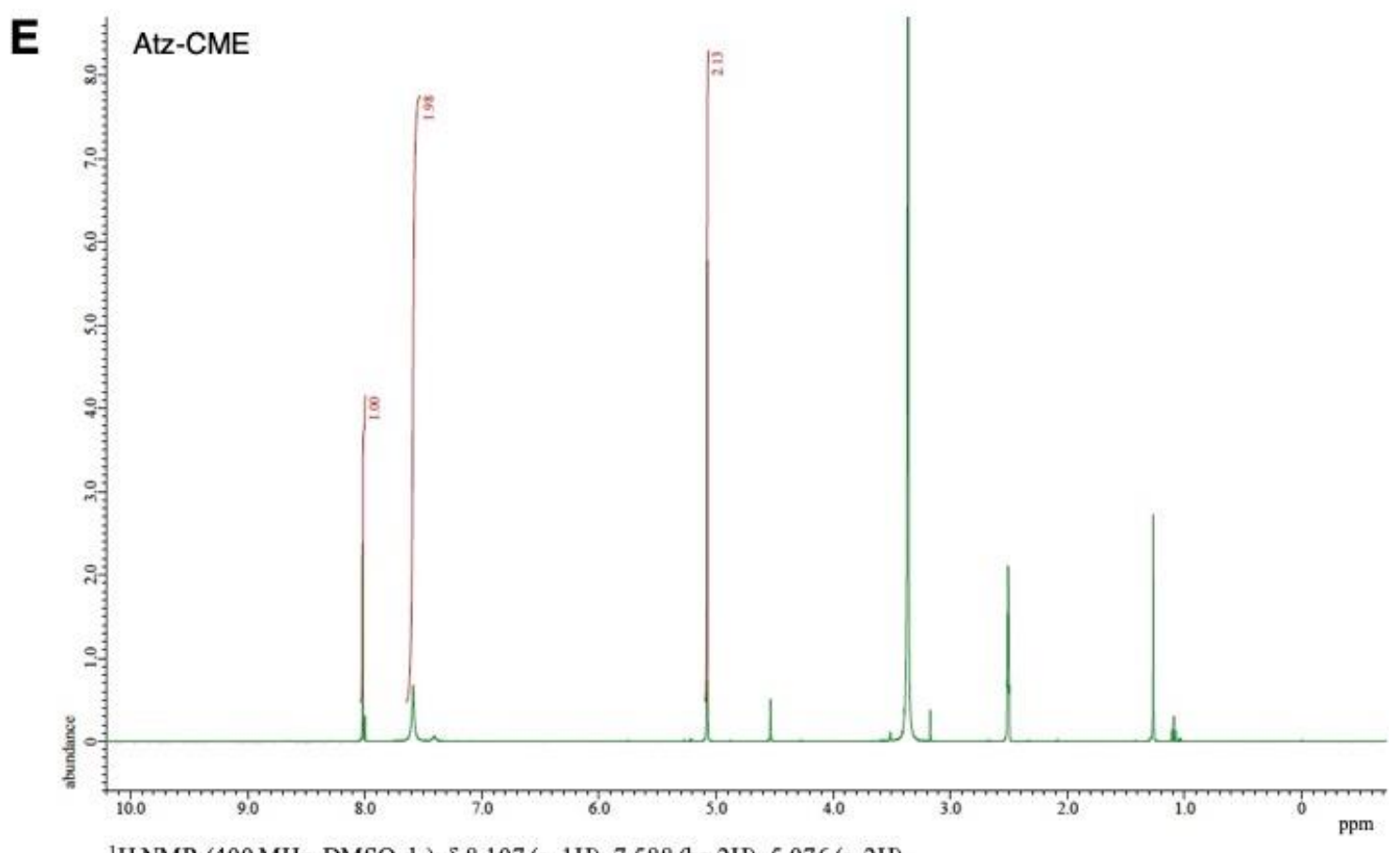

${ }^{1} \mathrm{H}$ NMR (400 MHz, DMSO-d $\left.{ }_{6}\right): \delta 8.107(\mathrm{~s}, 1 \mathrm{H}), 7.588(\mathrm{br}, 2 \mathrm{H}), 5.076(\mathrm{~s}, 2 \mathrm{H})$

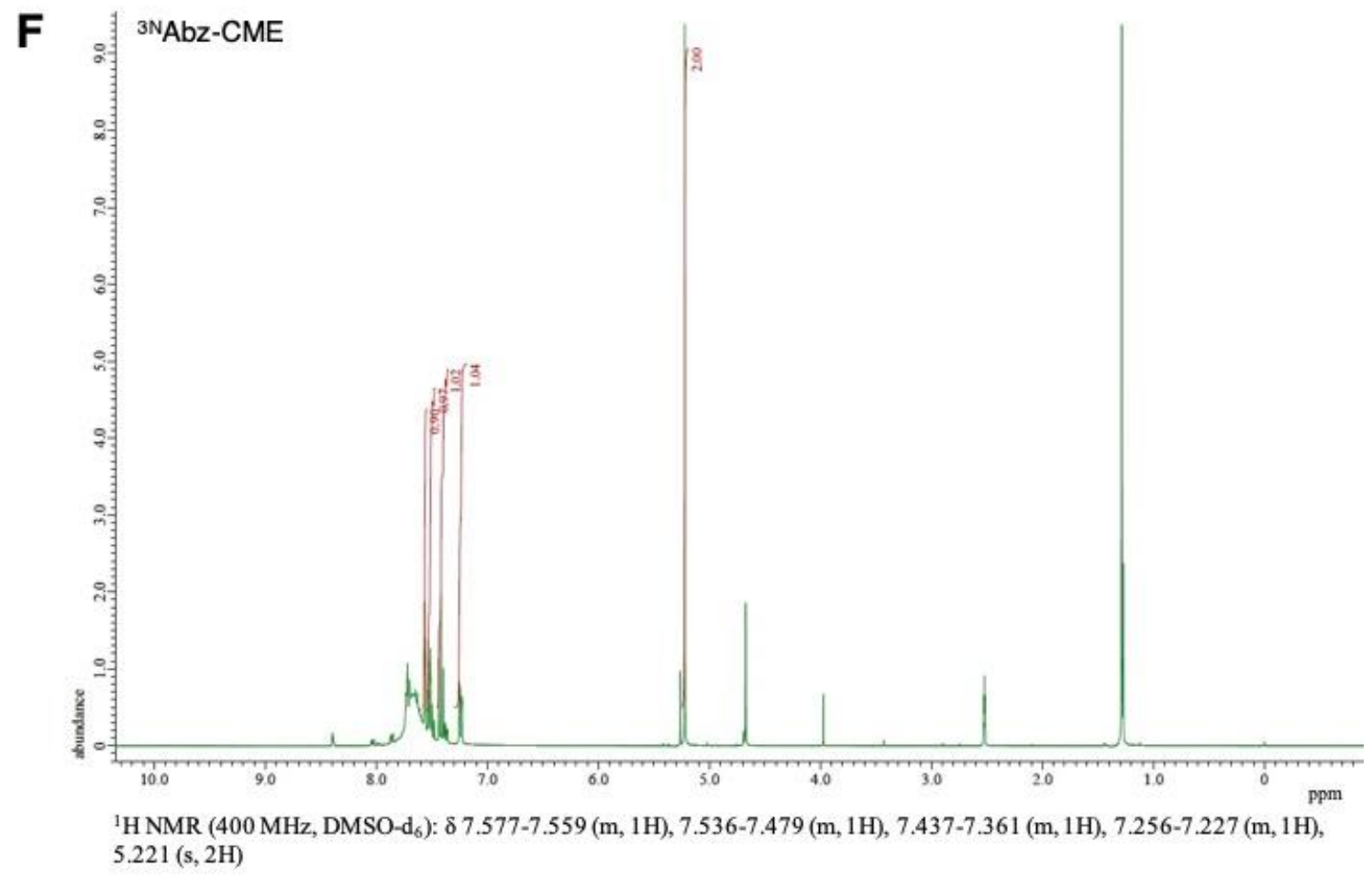

Supplementary Figure S2, continued. 
A $A b z$

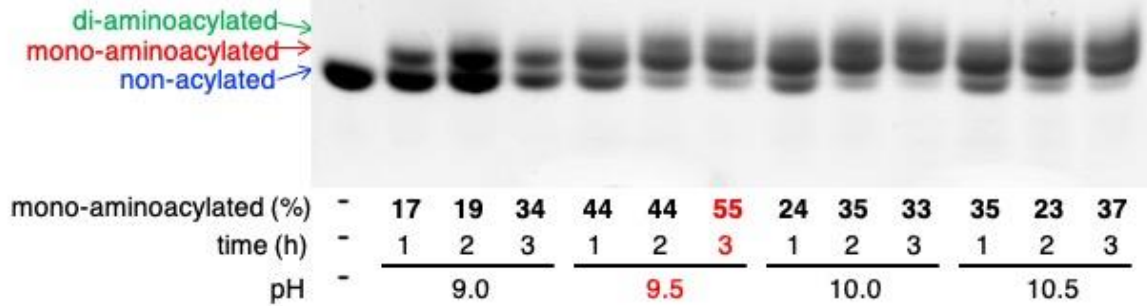

B $\mathrm{Abz}^{\mathrm{5OH}}$

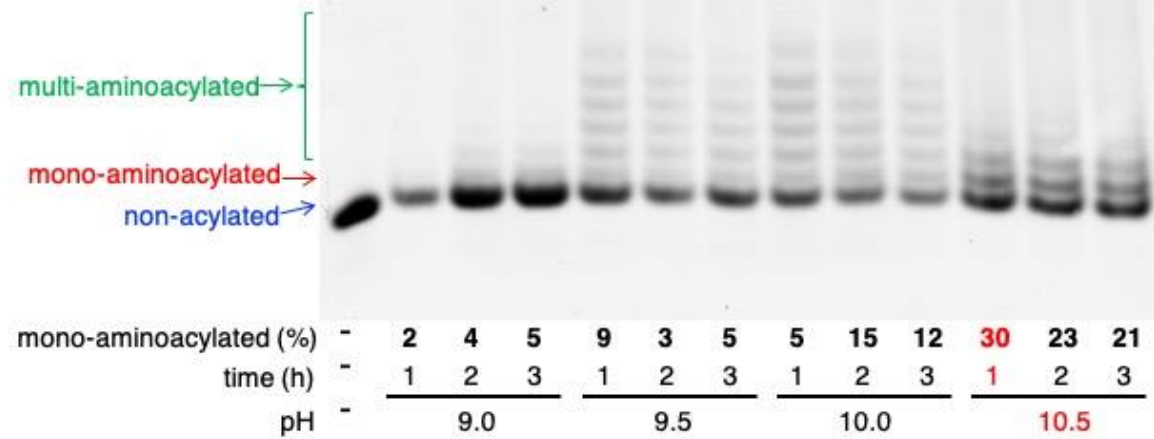

C $\mathrm{Abz}^{\mathrm{5OM}}$

di-aminoacylated $\gg$ mono-aminoacylated $\rightarrow$ non-acylated

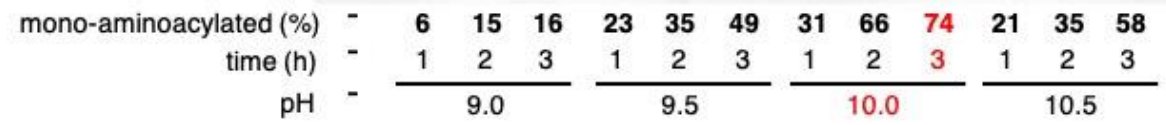

D $A b z^{5 F}$

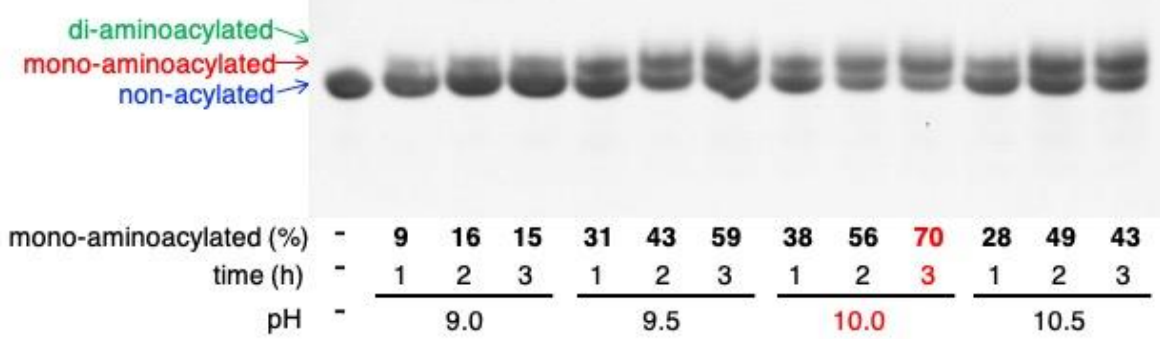

Supplementary Figure S3. Aminoacylation of $\mu \mathrm{hRNA}$ using amino acid NCAs analyzed by acid denaturing PAGE. Preparation of Abz- $\mu$ hRNA (A), Abz ${ }^{5 \mathrm{OH}_{-}} \mu \mathrm{hRNA}$ (B), $\mathrm{Abz}^{5 \mathrm{OMe}}-\mu \mathrm{hRNA}$ (C), and $\mathrm{Abz}^{5 \mathrm{~F}}-\mu \mathrm{hRNA}$ (D). Bands were detected by ethidium bromide staining. Red arrows indicate the positions of desired mono-aminoacyl- $\mu$ hRNAs. Green and blue arrows are the positions of multi-aminoacylated and unreacted $\mu \mathrm{hRNAs}$, respectively. Red numbers indicate the optimal reaction conditions. 
A

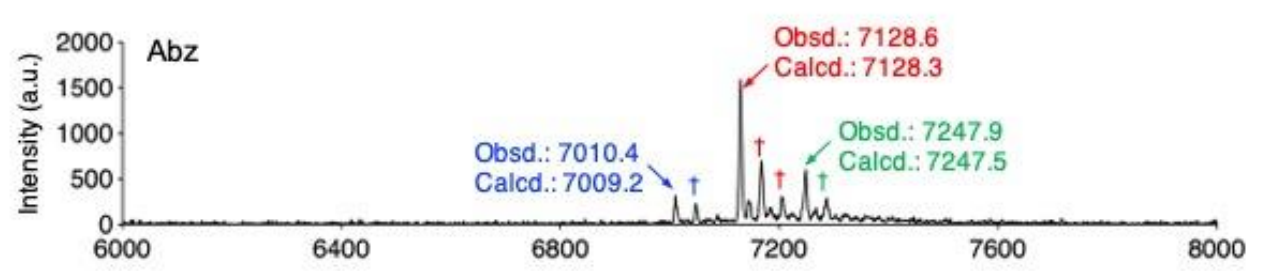

B

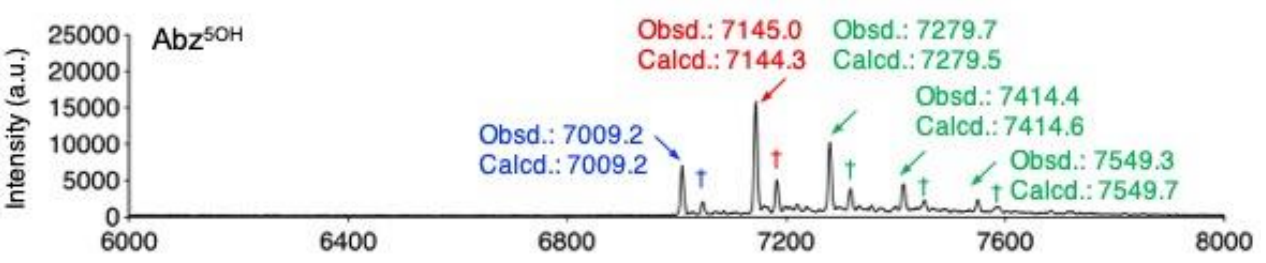

C ${ }^{4000}, \mathrm{Abz}^{50 \mathrm{M}}$

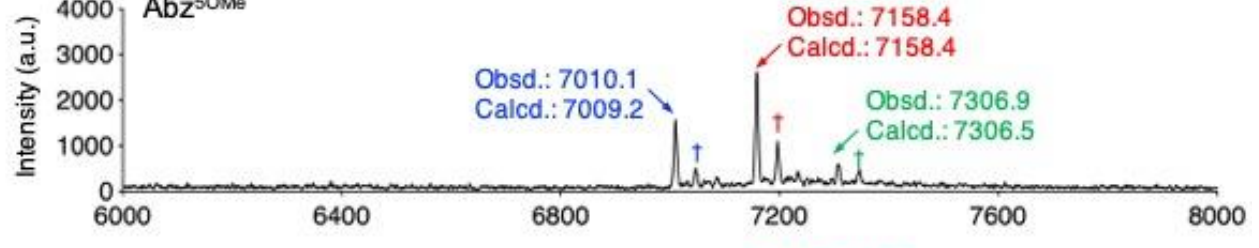

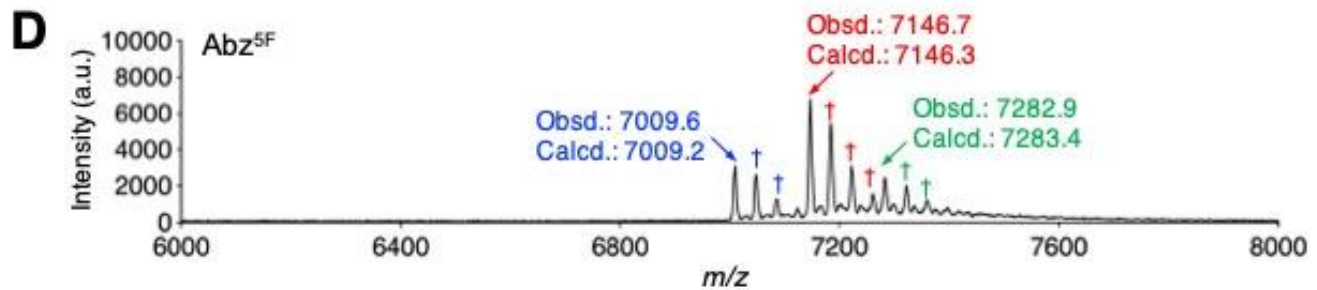

Supplementary Figure S4. MALDI-TOF mass spectra of aminoacyl- $\mu$ hRNAs prepared by means of amino acid NCAs. Analysis of Abz- $\mu$ hRNA (A), Abz ${ }^{5 \mathrm{OH}_{-}} \mu \mathrm{hRNA}$ (B), Abz ${ }^{5 \mathrm{OMe}_{-}}-\mu \mathrm{hRNA}$ (C), and $\mathrm{Abz}^{5 \mathrm{~F}}-\mu \mathrm{hRNA}$ (D). Red arrows indicate the peaks of the mono-aminoacyl- $\mu$ hRNAs. Green and blue arrows are the peaks of multi-aminoacylated and unreacted $\mu$ hRNAs, respectively. Observed and calculated $\mathrm{m} / \mathrm{z}$ values of the $[\mathrm{M}+\mathrm{H}]^{+}$ions are shown. $\dagger$ indicates potassium adducts. 

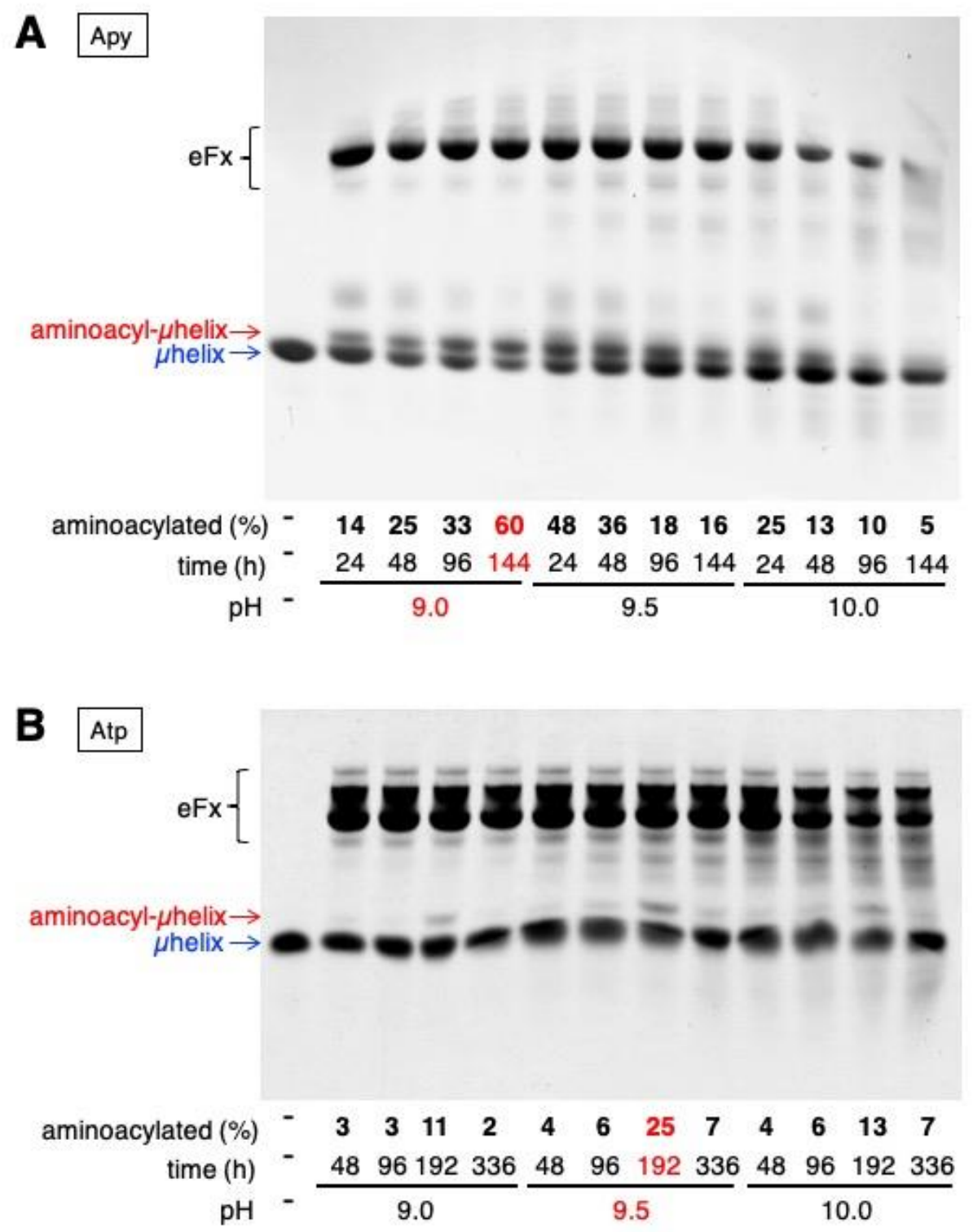

Supplementary Figure S5. Aminoacylation of $\mu$ hRNA using CME-activated amino acids and eFx analyzed by acid denaturing PAGE. Preparation of Apy- $\mu$ hRNA (A), Atp- $\mu$ hRNA (B), Atz- $\mu$ hRNA (C), and ${ }^{3 N} \mathrm{Abz}-\mu$ hRNA (D). Bands were detected by ethidium bromide staining. Red arrows indicate the positions of desired mono-aminoacyl- $\mu$ hRNAs. Blue arrows are the positions of unreacted $\mu \mathrm{hRNAs}$. 


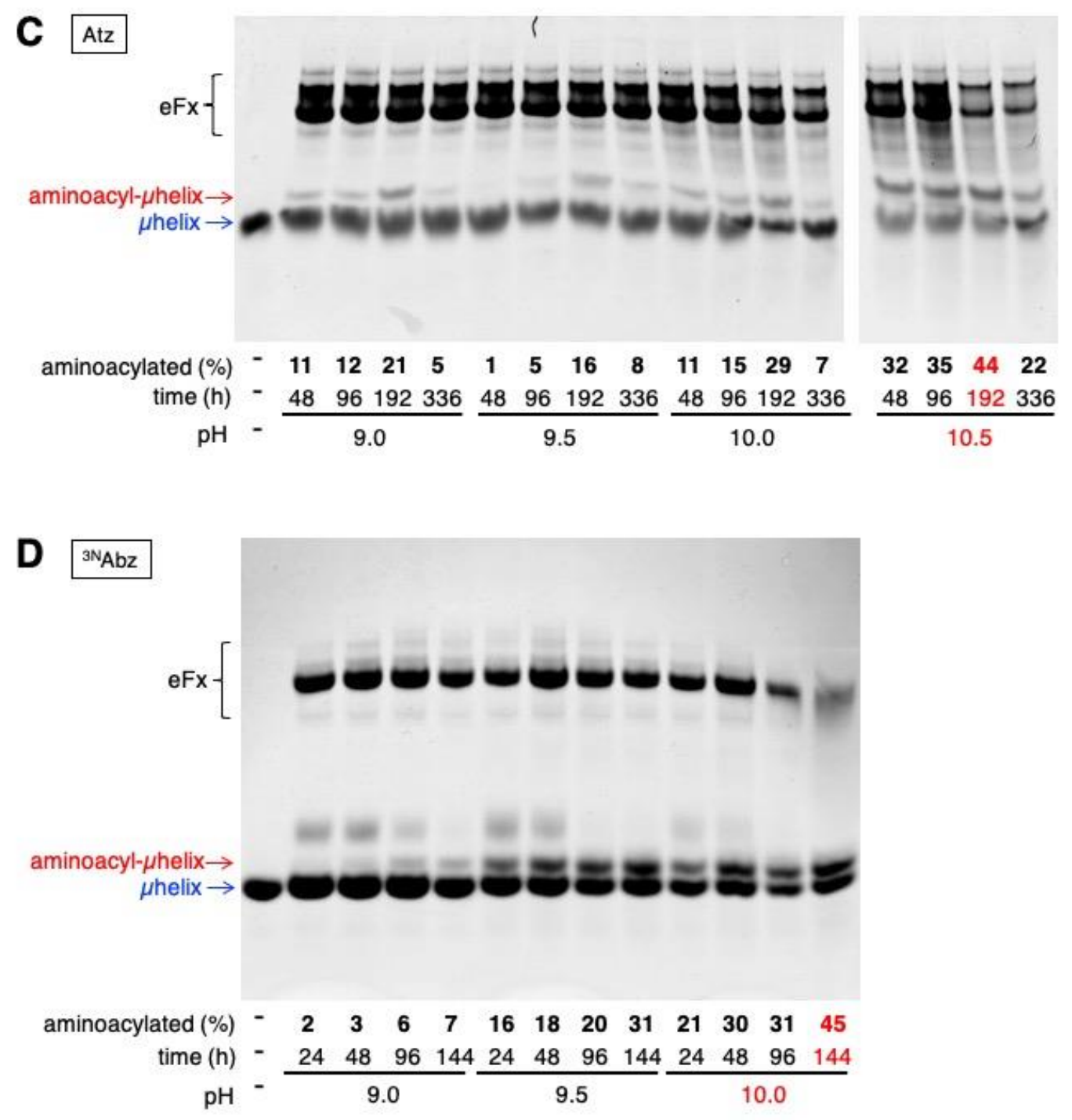

Supplementary Figure S5, continued. 

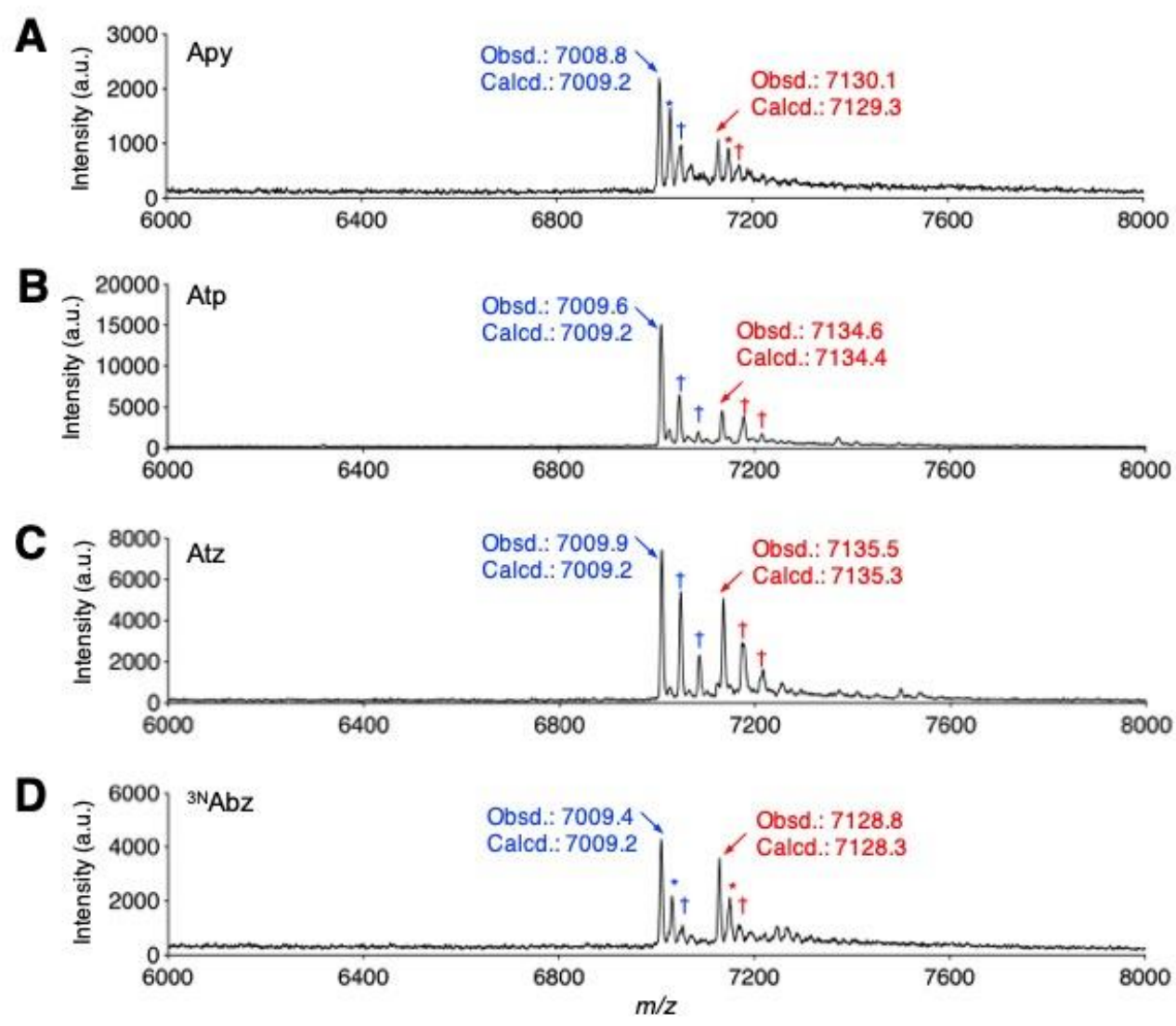

Supplementary Figure S6. MALDI-TOF mass spectra of aminoacyl- $\mu$ hRNAs prepared by eFx. Analysis of Apy- $\mu$ hRNA (A), Atp- $\mu$ hRNA (B), Atz- $\mu$ hRNA (C), and ${ }^{3 N} A b z-\mu h R N A$ (D). Red arrows indicate the peaks of the mono-aminoacyl- $\mu$ hRNAs. Green and blue arrows are the peaks of multi-aminoacylated and unreacted $\mu$ hRNAs, respectively. Observed and calculated $\mathrm{m} / \mathrm{z}$ values of the $[\mathrm{M}+\mathrm{H}]^{+}$ions are shown. ${ }^{*}$ and $\dagger$ indicates sodium and potassium adducts, respectively. 


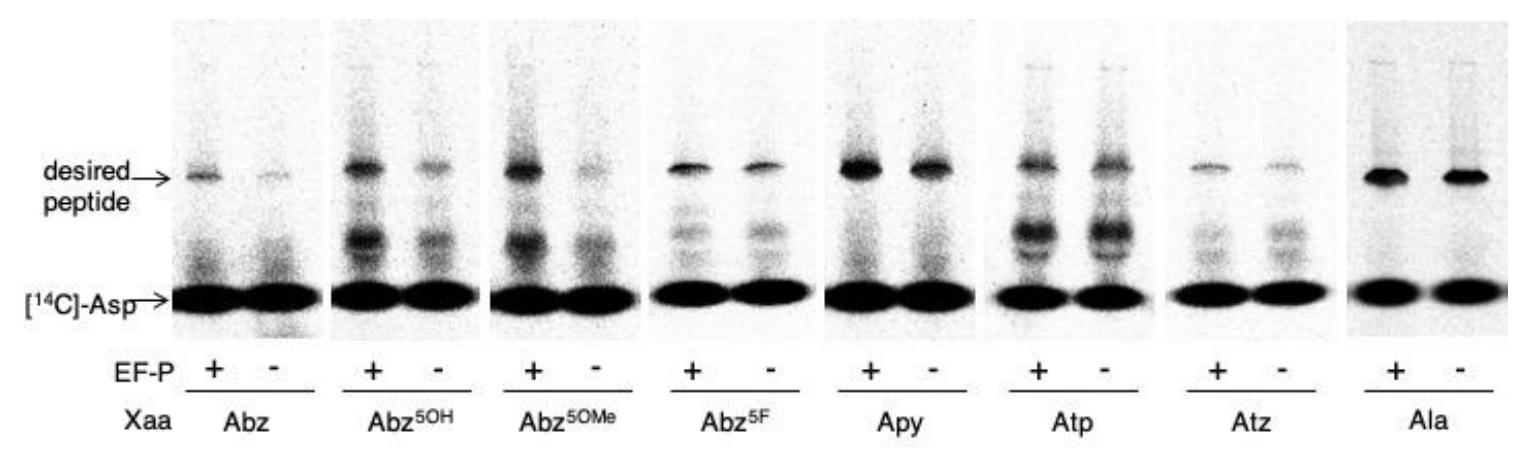

Supplementary Figure S7. Tricine SDS-PAGE analysis of model peptides rP1 containing Abz derivatives. See Figure $2 \mathrm{C}$ for quantification of the bands.

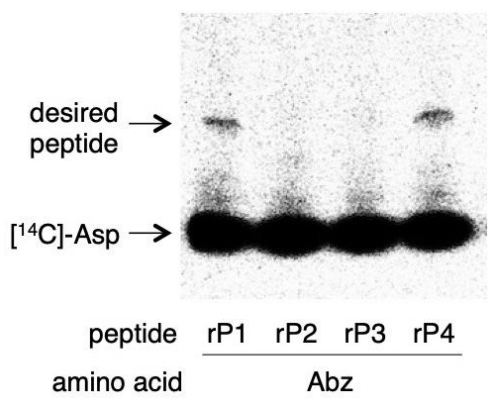

Supplementary Figure S8. Tricine SDS-PAGE analysis of model peptides rP1-rP4 containing Abz. Translation of peptides was carried out in the presence of EF-P. See Figure 3B for quantification of the bands. 


\section{Materials and methods}

\section{Preparation of tRNAs and flexizymes}

tRNAs and flexizymes (dFx and eFx) were synthesized by in vitro transcription. $\mu$ hRNA was purchased from Eurofin Genomics. The template DNAs for transcription were prepared by an extension reaction using forward and reverse extension primer pairs, followed by a PCR using forward and reverse PCR primer pairs (see Supplementary Table S2 for the sequences). Extension reaction was initiated at $95^{\circ} \mathrm{C}$ for $1 \mathrm{~min}$, followed by 5 cycles of $50^{\circ} \mathrm{C}$ and $72^{\circ} \mathrm{C}$ for 1 min each in a $10 \mu \mathrm{L}$ solution containing $50 \mathrm{mM} \mathrm{KCl}, 10 \mathrm{mM}$ Tris- $\mathrm{HCl}(\mathrm{pH} 9.0), 0.1 \%(\mathrm{v} / \mathrm{v})$ Triton X-100, $2.5 \mathrm{mM} \mathrm{MgCl}_{2}, 250 \mu \mathrm{M}$ dNTP mix, $2 \mu \mathrm{M}$ each forward and reverse extension primers, and $60 \mathrm{nM}$ Taq DNA polymerase. Then, $2 \mu \mathrm{L}$ of the extension product was mixed with a $200 \mu \mathrm{L}$ solution containing $50 \mathrm{mM} \mathrm{KCl}, 10$ $\mathrm{mM}$ Tris- $\mathrm{HCl}(\mathrm{pH} 9.0), 0.1 \%(\mathrm{v} / \mathrm{v})$ Triton X-100, $2.5 \mathrm{mM} \mathrm{MgCl}_{2}, 250 \mu \mathrm{M}$ dNTP mix, $0.5 \mu \mathrm{M}$ each forward and reverse PCR primers, and $60 \mathrm{nM}$ Taq DNA polymerase. PCR was performed by 14 cycles of $40 \mathrm{sec}$ at $94^{\circ} \mathrm{C}, 40 \mathrm{sec}$ at $50^{\circ} \mathrm{C}$, and $40 \mathrm{sec}$ at $72^{\circ} \mathrm{C}$. The amplified DNA was subjected to phenol/chloroform extraction and ethanol precipitation. The resulting DNA pellet was dissolved in the following transcription reaction mixture: $40 \mathrm{mM}$ Tris- $\mathrm{HCl}(\mathrm{pH} 8.0), 22.5 \mathrm{mM} \mathrm{MgCl}, 1 \mathrm{mM}$ DTT, 1 $\mathrm{mM}$ spermidine, $0.01 \%$ Triton X-100, $5 \mathrm{mM}$ NTP mix, $0.04 \mathrm{U} / \mu \mathrm{L}$ RNasin RNase inhibitor (Promega), $0.12 \mu \mathrm{M}$ T7 RNA polymerase, and the DNA template obtained by the PCR. Transcription reaction was carried out at $37^{\circ} \mathrm{C}$ for $16 \mathrm{~h}$. For tRNA transcription, $5 \mathrm{mM}$ GMP was added, and instead the concentration of NTP mix was reduced to $3.75 \mathrm{mM}$. The transcribed RNAs were treated with RQ1 DNase (Promega) at $37^{\circ} \mathrm{C}$ for $30 \mathrm{~min}$, and then purified by $8 \%$ (tRNAs) or $12 \%$ (flexizymes) polyacrylamide gel containing $6 \mathrm{M}$ urea.

\section{Aminoacylation of $\mu \mathrm{hRNA}$ and tRNAs}

Isatoic anhydride, 5-hydroxyisatoic anhydride, 5-methoxyisatoic anhydride, and 5-fluoroisatoic anhydride were purchased from Tokyo Chemical Industry, FUJIFILM Wako Pure Chemical, Combi-Blocks, and BLD Pharm, respectively. Aminoacylation using those NCAs was conducted at $25^{\circ} \mathrm{C}$ for $1-3 \mathrm{~h}$ in a $25-\mu \mathrm{L}$ reaction mixture containing $80 \mu \mathrm{M} \mu \mathrm{hRNA}$ or tRNA with $50 \mathrm{mM}$ bicine-KOH ( $\mathrm{pH} 9.0)$ or CHES-KOH (pH 9.5 or 10.0) or CAPS-KOH (pH 10.5), and 50\% acetonitrile. Concentration of NCAs was $10 \mathrm{mM}$, except for 5-fluoroisatoic anhydride $(8 \mathrm{mM})$.

${ }^{3 \mathrm{~N}} \mathrm{Abz}$, Apy, Atp, and Atz were pre-activated as CME forms by the following method: $0.25 \mathrm{mmol}$ $N$-Boc-amino acid was dissolved in $100 \mu \mathrm{L} N, N$-dimethylformamide (DMF), mixed with $100 \mu \mathrm{L}$ chloroacetonitrile, and $40 \mu \mathrm{L}$ triethylamine (TEA), and stirred at room temperature for $16 \mathrm{~h}$. Then, 4 $\mathrm{mL}$ diethylether was added and the solution was washed with $1 \mathrm{M} \mathrm{HCl}\left(3 \mathrm{~mL}\right.$ x2), saturated $\mathrm{NaHCO}_{3}$ in water $(3 \mathrm{~mL} \times 2)$, and saturated $\mathrm{NaCl}$ in water $(2 \mathrm{~mL}$ x1). The organic layer was recovered, dried over $\mathrm{Na}_{2} \mathrm{SO}_{4}$, and concentrated under reduced pressure. Then, the Boc group was deprotected in 800 $\mu \mathrm{L}$ trifluoroacetic acid (TFA) at room temperature for $40 \mathrm{~min}$. After removing TFA under reduced pressure, the resulting amino acid-CME was washed five times with $2 \mathrm{~mL}$ diethylether and analyzed by NMR (Supplementary Figure S2C-F). The yields of ${ }^{3 \mathrm{~N}} \mathrm{Abz}-\mathrm{CME}$, Apy-CME, Atp-CME, and Atz-CME were 99\%, 51\%, 95\%, and 97\%, respectively. (1S,2S)-2-ACPC, MeSer, and D-Cys were pre-activated as 3,5-dinitrobenzyl ester (DBE) forms, and ${ }^{C l A c} \mathrm{D}-\mathrm{Phe}$ and ${ }^{\mathrm{ClAc}} \mathrm{D}-\mathrm{Tyr}$ were pre-activated as CME forms according to the previously reported methods. ${ }^{1-6}$ Then, these amino acids were charged onto $\mu \mathrm{hRNA}$ or tRNAs using flexizymes (dFx for DBE or eFx for CME). Aminoacylation of ${ }^{3 \mathrm{~N}} \mathrm{Abz}$, Apy, Atp, and Atz was performed at $4^{\circ} \mathrm{C}$ for $24-336 \mathrm{~h}$ in a reaction mix containing $600 \mathrm{mM} \mathrm{MgCl}$, $20 \%$ DMSO, $25 \mu \mathrm{M}$ eFx, $25 \mu \mathrm{M} \mu \mathrm{hRNA}$ or tRNA, and $20 \mathrm{mM}$ activated amino acid. The $\mathrm{pH}$ of the mixture was adjusted by $50 \mathrm{mM}$ bicine-KOH (pH 9.0) or CHES-KOH (pH 9.5 or 10.0) or

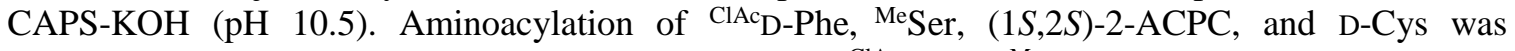
performed at $4{ }^{\circ} \mathrm{C}$ in $50 \mathrm{mM}$ HEPES-KOH $(\mathrm{pH} 7.5)$ for ${ }^{\mathrm{ClAc}} \mathrm{D}-\mathrm{Phe}$, Meser, and D-Cys or Bicine-KOH (pH 8.7) for (1S,2S)-2-ACPC, $600 \mathrm{mM} \mathrm{MgCl} 2,20 \%$ DMSO, $25 \mu \mathrm{M} \mathrm{dFx}$ or eFx, $25 \mu \mathrm{M}$ tRNA, and 5 $\mathrm{mM}$ activated amino acid. The incubation time was $2 \mathrm{~h}$ for ${ }^{\mathrm{ClAc}}{ }_{\mathrm{D}-\mathrm{Phe}}, 6 \mathrm{~h}$ for ${ }^{\mathrm{Me}} \mathrm{Ser}$ and D-Cys, and 16 $\mathrm{h}$ for $(1 S, 2 S)$-2-ACPC. The resulting aminoacyl-RNAs were subjected to ethanol precipitation, and the pellets were washed with $70 \%$ ethanol twice and resuspended in $1 \mathrm{mM}$ sodium acetate (pH 5.2). 
20 pmol aminoacyl- $\mu$ hRNAs were analyzed on $20 \%$ polyacrylamide gels containing $6 \mathrm{M}$ urea. The $\mathrm{pH}$ was adjusted at 5.2 by $50 \mathrm{mM}$ sodium acetate ( $\mathrm{pH}$ 5.2), except for analyses of Atp- $\mu \mathrm{hRNA}$ and Atz- $\mu$ hRNA (50 mM sodium acetate, $\mathrm{pH} 3.5$ ). Electrophoresis was carried out at $120 \mathrm{~V}$ for $2.5 \mathrm{~h}$, followed by ethidium bromide staining and detection using a Typhoon FLA 7000 (GE Healthcare).

\section{Translation and electrophoresis of model peptides}

The template DNAs of mR1-10 were synthesized by extension and PCR using forward and reverse primer pairs (see Supplementary Table S2 for the sequences), and purified by phenol/chloroform extraction and ethanol precipitation. Conditions for the extension and PCR were the same as those for the preparation of DNA templates of tRNAs and flexizymes. The resulting DNAs were dissolved in water and added to the FIT system containing T7 RNA polymerase for transcription/translation-coupled reactions. Translation of model peptides was carried out at $37^{\circ} \mathrm{C}$ for $30 \mathrm{~min}$ in an $E$. coli reconstituted translation system of the following composition: $50 \mathrm{mM}$ HEPES-KOH (pH 7.6), $100 \mathrm{mM}$ potassium acetate, $12.3 \mathrm{mM}$ magnesium acetate, $2 \mathrm{mM}$ ATP, $2 \mathrm{mM}$ GTP, $1 \mathrm{mM}$ CTP, $1 \mathrm{mM}$ UTP, $20 \mathrm{mM}$ creatine phosphate, $0.1 \mathrm{mM}$ 10-formyl-5,6,7,8-tetrahydrofolic acid, $2 \mathrm{mM}$ spermidine, $1 \mathrm{mM}$ DTT, $1.5 \mathrm{mg} / \mathrm{mL}$ E. coli total tRNA, $1.2 \mu \mathrm{M}$ E. coli ribosome, $0.6 \mu \mathrm{M}$ methionyl-tRNA formyltransferase, $2.7 \mu \mathrm{M}$ IF1, $3 \mu \mathrm{M} \mathrm{IF} 2,1.5 \mu \mathrm{M} \mathrm{IF} 3,0.1 \mu \mathrm{M}$ EF-G, $20 \mu \mathrm{M}$ EF-Tu/Ts, $0.25 \mu \mathrm{M}$ RF2, $0.17 \mu \mathrm{M}$ RF3, $0.5 \mu \mathrm{M}$ RRF, $4 \mu \mathrm{g} / \mathrm{mL}$ creatine kinase, $3 \mu \mathrm{g} / \mathrm{mL}$ myokinase, $0.1 \mu \mathrm{M}$ inorganic pyrophosphatase, $0.1 \mu \mathrm{M}$ nucleotide diphosphate kinase, $0.1 \mu \mathrm{M}$ T7 RNA polymerase, $0.13 \mu \mathrm{M}$ AspRS, $0.11 \mu \mathrm{M}$ LysRS, $0.03 \mu \mathrm{M}$ MetRS, $0.68 \mu \mathrm{M}$ PheRS, $0.02 \mu \mathrm{M}$ TyrRS, $0.09 \mu$ M GlyRS, $0.05 \mathrm{mM}\left[{ }^{14} \mathrm{C}\right]$-Asp, $0.5 \mathrm{mM}$ Lys, $0.5 \mathrm{mM}$ Met, $0.5 \mathrm{mM}$ Phe, $0.5 \mathrm{mM}$ Tyr, $0.5 \mathrm{mM}$ Gly, $25 \mu \mathrm{M}$ each pre-charged aminoacyl-tRNA, and $0.5 \mu \mathrm{M}$ DNA template. $5 \mu \mathrm{L}$ of stop solution [0.9 M Tris- $\mathrm{HCl}$ (pH 8.45), 8\% SDS, 30\% glycerol, and $0.001 \%$ xylene cyanol] was added to $5 \mu \mathrm{L}$ reaction mix, and incubated at $95^{\circ} \mathrm{C}$ for $3 \mathrm{~min}$. Then, the samples were subjected to $15 \%$ Tricine SDS-PAGE, and analyzed by autoradiography using a Typhoon FLA 7000 (GE Healthcare). Expression levels of peptides were calculated by the intensity of the product band divided by the total intensity of $\left[{ }^{14} \mathrm{C}\right]-\mathrm{Asp}$, and multiplied by $50 / 5(\mathrm{pmol} / \mu \mathrm{L}) .50$ is the concentration of $\left[{ }^{14} \mathrm{C}\right]-\mathrm{Asp}$ in the FIT system $(\mathrm{pmol} / \mu \mathrm{L})$, and 5 is the number of $\left[{ }^{14} \mathrm{C}\right]$-Asp introduced into the model peptides.

\section{MALDI-TOF mass spectrometry of model peptides and aminoacyl- $\mu \mathrm{hRNAs}$}

For MALDI-TOF MS analysis, the translation reaction was carried out for $60 \mathrm{~min}$ in the presence of $0.5 \mathrm{mM}$ cold Asp instead of $\left[{ }^{14} \mathrm{C}\right]$-Asp. For translation of macrocyclic peptides rP5-rP10, MetRS, Met, and 10-formyl-5,6,7,8-tetrahydrofolic acid were omitted from the above reaction mixture. For rP5-rP7, PheRS and Phe were also omitted, and instead the following aminoacyl-tRNA synthetases and the corresponding amino acids were added: $0.04 \mu \mathrm{M}$ SerRS, $0.02 \mu \mathrm{M}$ HisRS, $0.16 \mu \mathrm{M}$ ProRS, $0.09 \mu \mathrm{M}$ ThrRS, $0.03 \mu \mathrm{M}$ ArgRS, $0.38 \mu \mathrm{M}$ AsnRS, $0.73 \mu \mathrm{M}$ AlaRS, $0.02 \mu \mathrm{M}$ ValRS, $0.5 \mathrm{mM}$ Ser, $0.5 \mathrm{mM}$ His, $0.5 \mathrm{mM}$ Pro, $0.5 \mathrm{mM} \mathrm{Thr}, 0.5 \mathrm{mM}$ Arg, $0.5 \mathrm{mM}$ Asn, $0.5 \mathrm{mM}$ Ala, and $0.5 \mathrm{mM}$ Val. The translation reaction mixture was diluted with an equal volume of $2 \times$ HBS buffer $[100 \mathrm{mM}$ HEPES-KOH (pH 7.6), $300 \mathrm{mM} \mathrm{NaCl}$, mixed with 5- $\mu$ L ANTI-FLAG M2 affinity gel (Sigma), and incubated for $30 \mathrm{~min}$ at room temperature. The affinity gel was washed with $25 \mu \mathrm{L}$ of $1 \times \mathrm{HBS}$ buffer [50 mM HEPES-KOH (pH 7.6), $150 \mathrm{mM} \mathrm{NaCl}$ twice. Then, the bound peptides were eluted from the gel by adding $20 \mu \mathrm{L}$ of $0.2 \%$ trifluoroacetic acid, desalted with SPE C-tip (Nikkyo Technos), and co-crystallized with $\alpha$-cyano-4-hydroxycinnamic acid. For external mass calibration, peptide calibration standard II (Bruker Daltonics) was used. Analyses were carried out using UltrafleXtreme (Bruker Daltonics) in a reflector/positive mode.

The aminoacyl- $\mu$ hRNAs were desalted with SPE C-tip (Nikkyo Technos) and co-crystalized with 3-hydroxypicolinic acid, and then analyzed by UltrafleXtreme (Bruker Daltonics) in a linear/positive mode.

\section{References for supplementary information}

(1) Murakami, H.; Ohta, A.; Ashigai, H.; Suga, H. A highly flexible tRNA acylation method for non-natural polypeptide synthesis. Nat. Methods 2006, 3, 357-359. 
(2) Saito, H.; Kourouklis, D.; Suga, H. An in vitro evolved precursor tRNA with aminoacylation activity. EMBO J. 2001, 20, 1797-1806.

(3) Kawakami, T.; Murakami, H.; Suga, H. Messenger RNA-programmed incorporation of multiple $\mathrm{N}$-methyl-amino acids into linear and cyclic peptides. Chem. Biol. 2008, 15, 32-42.

(4) Hayashi, Y.; Morimoto, J.; Suga, H. In vitro selection of anti-Akt2 thioether-macrocyclic peptides leading to isoform-selective inhibitors. ACS Chem. Biol. 2012, 7, 607-613.

(5) Fujino, T.; Goto, Y.; Suga, H.; Murakami, H. Reevaluation of the D-amino acid compatibility with the elongation event in translation. J. Am. Chem. Soc. 2013, 135, 1830-1837.

(6) Katoh, T.; Sengoku, T.; Hirata, K.; Ogata, K.; Suga, H. Ribosomal synthesis and de novo discovery of bioactive foldamer peptides containing cyclic $\beta$-amino acids. Nat. Chem. 2020, in press. 